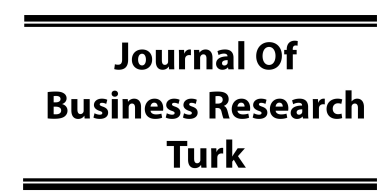

www.isarder.org

\title{
The Mediating Effect of Customer Satisfaction on the Relationship Between Perceived Value and Word-of-Mouth in the Airline Industry
}

\author{
Hasan Emin GÜRLER \\ Akdeniz University \\ Faculty of Applied Sciences \\ Department of International Trade and \\ Logistics, Antalya, Turkey \\ orcid.org/0000-0002-5813-1631 \\ hasangurler@akdeniz.edu.tr
}

\author{
Ramazan ERTURGUT* \\ Akdeniz University \\ Faculty of Applied Sciences \\ Department of International Trade and \\ Logistics, Antalya, Turkey \\ orcid.org/0000-0002-0240-5787 \\ rerturgut@akdeniz.edu.tr
}

\begin{abstract}
In recent years, significant developments have taken place in the airline industry. It is thought that the interest in the sector will increase continuously in the coming years. So the competition in the sector will be more intense as it is now. In this intense competitive environment, concepts such as customer satisfaction and customer loyalty, which are important determinants of sales and profitability of firms, will become as important as they are now. It is necessary for customers to have positive perception of the product or service offered by the firm in order to be satisfied. In addition, customer satisfaction may result in referrals to other people about the firm. Therefore, in this study, the mediating effect of customer satisfaction was investigated through online questionnaire. Factor analysis and regression analysis were performed in the study. As a result, the customer satisfaction has a full mediator effect between the perceived value and the word-of-mouth.
\end{abstract}

Keywords: Customer Satisfaction, Perceived Value, Word-of-Mouth, Airline Industry, Mediating Effect.

\section{Introduction}

The airline industry is a global service industry that is experiencing intense competition and growing with the developing technology, providing economically important contributions (Rothkopf and Wald, 2008). This industry plays an important role in the development of tourism and international trade as well as economy. According to estimates by the International Air Transport Association (IATA), people who prefer air transport spend about $\$ 650$ billion in 2016. In addition, the value of commercial commodities transported by air is around 5.5 trillion dollars. The most important reasons for this significant increase in passenger and freight traffic are; the reduction of air transport costs and the further development of links (IATA, 2017). At the same time, this industry is one of the fastest growing industries in the global economy. In the last two decades that we have left behind, this industry has grown at an annual average rate of 5\%. This industry, which is a significant contributor to the Gross 


\section{H. E. Gürler - R. Erturgut 10/1 (2018) 1-16}

Domestic Product, creates significant employment in all countries (Vespermann and Wald, 2011). The impact of the industry on the Gross Domestic Product is about $\$ 665$ billion, and this industry employs a total of 62.7 million people worldwide (ATAG, 2016). Despite the current stagnation in the market and the crises experienced in the sector, it is estimated that this industry will continue to remain a global industry with an annual average growth rate of $4.2 \%-5.1 \%$ (Vespermann and Wald, 2011).

Turkey is one of the fastest growing countries in the airline industry. In recent years, the number of passengers has increased significantly in both local and international flights (Karaca, 2015). Particularly in 2003, with the adoption of the regional air transport policy, private airline companies were allowed to travel anywhere in the country. With this development, there has been a significant increase in the number of airlines operating in the sector and the number of flight points (Iş1k, 2010). In the last thirteen years, the number of aircraft in our airline companies increased by $233 \%$, seat capacity by $264 \%$, cargo capacity by $502 \%$. In addition, the number of destinations flying out of Turkey has been 341 . As of the end of 2016, there are 540 aircraft in the civil aviation companies operating in Turkey. There has been a progress in the sector over expectations of international organizations in estimates of the sector. However, the predictions of international organizations and big aircraft makers are that the growth in the sector will continue until the 2030s (DGCA, 2016). Air Transport Action Group (ATAG) estimates that by 2034 the number of people who prefer air transportation worldwide will be 6.9 billion per year, while the number of people employed in the sector will be 99.1 million (ATAG, 2016). In the light of foresight competition in the sector will become even more intense, and customer satisfaction, which is prioritized by all service-oriented industries including the airline industry (Arif et al., 2013), will become an even more important criterion. Because customer satisfaction is an important guide for monitoring and improving the current and potential performance of companies. At the same time, customer satisfaction has a significant impact on customers' loyalty, the intention of word-of-mouth and repurchasing behavior (Meesala and Paul, 2016). This demonstrates how important it is for companies that want to survive in intense competition and sustainable competitive advantage to offer products or services that will meet customer expectations and ensure they are satisfied with the value they perceive.

The relationship between perceived value, word-of-mouth, and customer satisfaction variables in the literature has mostly been studied in binary terms. However, regarding these concepts, the number of studies that measure the effect of a third variable on the relationship between one variable and the other is very small. Therefore, in this study, the mediating effect of customer satisfaction on the linear relationship between perceived value and word-of-mouth was analyzed. Thus, a significant relationship between perceived value and word-of-mouth was introduced to explain whether a significant relationship could be maintained if the customer satisfaction variable was included, and it was aimed to include literary value and managerial inferences.

\section{Literature Review}

\section{Perceived Value-Customer Satisfaction Relationship}

The most extensive accepted definition of perceived value was made by Zeithaml (1988) (Yang et al., 2016). According to Zeithaml, consumers define the value in 4 


\section{H. E. Gürler - R. Erturgut 10/1 (2018) 1-16}

terms. These are; "low price", "what I want in a product", "the quality I get for the price I paid" and "what benefit will I get for the money I give". When we deal with these four terms as a whole; the perceived value is a general benefit assessment based on the perceived price of the consumer paying for the product received (Zeithaml, 1988). At the same time, the perceived value represents the balance between perceived benefits and perceived costs (Lai and Chen, 2011). The perceived value affects customer satisfaction as it can affect customers' attractiveness or pushing, and as a result, it is seen as a component of customer satisfaction (Qin et al., 2010). There are studies in the literature that show that the perceived value may be a more important factor that determines consumers' intent to purchase again in comparison to satisfaction or quality (Cronin et al., 2000; Petrick, 2004; Petrick and Backman, 2002; Woodruff, 1997). In some studies, perceived value is defined as the predecessor of intentions of satisfaction and behavior (Chen, 2008; Cronin et al., 2000; Petrick, 2004; Petrick and Backman, 2002). In addition, Jen and Hu set up a perceived value model in 2003 to determine the factors that affect consumers' intent to purchase again for public transport services. The results of the model show that the behavioral intentions of the consumers are significantly affected by the perceived value (Jen and $\mathrm{Hu}, 2003$ ). These studies show how important the perceived value is. However, it is also known that the perception of the product or service received by consumers for their price is positively related to their level of satisfaction (Chen and Tsai, 2008). There are several studies in the literature that perceived value affects consumers' satisfaction positively (Cronin et al., 2000; Gallarza and Saura, 2006; Mohd-Any et al., 2015; Al-Sabbahy et al., 2003; Williams and Soutar, 2009; Eggert and Ulaga, 2002; Hsu, 2006; Yang and Peterson, 2004; Lai, 2004; Turel and Serenko, 2006; Deng et al., 2010; Murray and Howat, 2002; Qin et al., 2010). The first hypothesis of the research that is inspired by these studies is as follows:

$\mathbf{H}_{1}$ : Perceived value has a significant and positive influence on customer satisfaction.

\section{Perceived Value-Word-of-Mouth Relationship}

Word-of-Mouth involves communicating the consumer's informal view of products and brands to other people. This view is derived from consumption experiences or advertisements (Wien and Olsen, 2017). Word-of-Mouth is at the center of the buying process. Consumers need the views of people who have previously purchased these products or services, especially with regard to products or services that are of high financial value ( $\mathrm{Lu}$ et al., 2016). This view can be traditionally verbally transmitted or transmitted electronically (Pollack, 2017). At the same time, word-ofmouth can be realized in two ways, positive and negative. Positive word-of-mouth involves positive feedback from customers who are satisfied with the experience they have had with a product or service. Negative word-of-mouth includes negative opinions that emphasize customers' dissatisfaction with the product or service (Mishra et al., 2016). Nevertheless, some consumers' views on products or services may emerge as a result of observations of global measures such as perceived value and quality, as well as observations of specific measures such as employee performance (Hartline and Jones, 1996).

There are only a few studies in the literature that examined the relationship between perceived value and word-of-mouth. Regarding these concepts, the mediating effect of oral communication concept on the perceived value of travel made for health purposes was investigated by $\mathrm{Lu}$ et al 2014. In the study, it was detected that word-of- 


\section{H. E. Gürler - R. Erturgut 10/1 (2018) 1-16}

mouth showed a full mediator effect on the perceived value ( $\mathrm{Lu}$ et al., 2014). In the study conducted by Hsu et al. In 2017, the relationship between electronic word-ofmouth and perceived value was investigated. As a result of the study, it has been found that the perceived value is positively influenced by the electronic word-of-mouth (Hsu et al., 2017). Hartline and Jones conducted a study in 1996 to examine whether customers' perceptions of employee performance and quality translate into word-ofmouth. As a result of the study, it has been determined that both the perceived value and the quality are converted into word-of-mouth actions and that the perceived value's effect on word-of-mouth is higher than quality's effect on word-of-mouth (Hartline and Jones, 1996). The second hypothesis of the research that is inspired by these studies is as follows:

$\mathbf{H}_{2}$ : Perceived value has a significant and positive influence on Word-of-Mouth.

\section{Customer Satisfaction-Word-of-Mouth Relationship}

Customer satisfaction is achieved when consumers' expectations are met with the benefits that the product or service offers (Tütüncü and Doğan, 2003). The customer has an expectation when buying a product or service. Satisfaction occurs when the benefit from the product or service overlaps or exceeds this expectation (Naktiyok and Küçük, 2003). Satisfaction is not a universal phenomenon and it is not possible for everyone to be equally satisfied with the same experience. Customers have different needs, objectives, and experiences that affect their expectations (Pizam et al., 2016).

Customer satisfaction is of great importance to companies as it intensively affects the intent to purchase again and the word-of-mouth action. Satisfaction strengthens positive attitudes towards the brand and increases the likelihood of re-purchasing from the same brand (Pizam and Ellis, 1999). At the same time, talks and advice from satisfied customers about the company or company's products or services initiate the process of acquiring new customers (Çatı and Koçoğlu, 2008). There are several studies in the literature that emphasize that the satisfied customer have advice about the company's products or services (Jiewanto et al., 2012; San-Martin et al., 2015; Hui et al., 2007; Webber, 2011; Jung and Seock, 2017; Kim et al., 2009; Maxham III and Netemeyer, 2002; Ranaweera and Prabhu, 2003). The third hypothesis of the research that is inspired by these studies is as follows:

$\mathbf{H}_{3}$ : Customer satisfaction has a significant and positive influence on Word-of-Mouth.

\section{Mediator Variable: Customer Satisfaction}

In this study, it was aimed to examine the mediating effect of customer satisfaction on the relationship between perceived value and word-of-mouth. There are several studies in the literature that examine the mediating effect of customer satisfaction (Pereira et al., 2016; Wahab et al., 2016; Usta and Memiş, 2009; Agus and Abdullah, 2000; Osman and Sentosa, 2013; Chumpitaz and Swaen, 2002; Srivastava and Rai, 2013; Al-Hawari and Ward, 2006). However, the number of studies regarding whether the mediating effect of customer satisfaction on the relationship between perceived value and word-of-mouth is very limited. Therefore, it is considered that if the customer satisfaction is a mediator variable, an important contribution will be made to the literature. So the last hypothesis of the research is designed as follows:

$\mathbf{H}_{4}$ : There is a mediation effect of customer satisfaction on the relationship between perceived value and word-of-mouth. 


\section{H. E. Gürler - R. Erturgut 10/1 (2018) 1-16}

\section{Research Design and Methodology}

An online questionnaire was conducted to examine the cause-effect relationships of perceived value, word-of-mouth, and customer satisfaction. In order to measure the perceived value, the expressions ( 3 questions) used in 2009 by Kuo et al. In order to measure the effect of word-of-mouth, we used the expressions used in 2007 by Marangoz (3 questions) and the expressions used by Calvo-Porral and Levy-Mangin in 2015 (4 questions) to measure customer satisfaction.

Customers who prefer air transportation in the study were selected as the target audience and were asked to complete the questionnaire if they used air transportation before the questionnaire. It has been stated that the target group must indicate the degree of participation for each expression in the questionnaire. The questionnaire form has been prepared via Google Forms. Convenience sampling method has been adopted in the study. In this direction, the questionnaire was sent between 10 March - 03 April 2017. Within the scope of the study, 192 valid questionnaires were obtained.

$55.7 \%$ of the respondents in the questionnaire are women and $44.3 \%$ are men. The age range of participants varies from 19 to 49, and participants aged 30 and 31 make up approximately $20 \%$ of all participants. When the educational status of the participants is examined; $77.1 \%$ of them are postgraduates, $20.3 \%$ are graduates, $2.6 \%$ are associate degree and previous graduates. The proportion of consumers with income 4000 Turkish Liras and over is 62.5\%; the rate of those with income between 3001-4000 Turkish Liras is \% 17,7; the rate of income between 2001-3000 Turkish Liras is $12 \%$; the rate of those with income between 1001-2000 Turkish Liras is 5.7\% and the rate of those with income less than 1000 Turkish Liras is 2,1\%. The proportion of respondents who stated that air transport is the primary preference for other modes of transport is the $81,2 \%$; the proportion of respondents who stated that air transport is not the preferred preference is $18.8 \%$.

\section{Results and Discussion}

Prior to testing the mediating effects of customer satisfaction variables, Reliability Analysis and Principal Component Analysis, one of the methods used in factor analysis, were used to determine the reliability and validity of the measurement means used in the research. According to Büyüköztürk (2002), when the factors are strong and the number of variables is low, the sample size between 100 and 200 is sufficient for factor analysis. However, as a universal rule, it is assumed that a sample with at least fivefold the number of variables is sufficient (Büyüköztürk, 2002). The number of data used in the study is 192, which is sufficient for analysis.

Reliability refers to the consistency between the ratings of participation that people have expressed about the expressions on the questionnaire. Cronbach's Alpha value resulting from the analysis is used to interpret to what extent the individual differences are incorrect and to what extent they are incorrectly calculated with respect to the expressions in the questionnaire (Büyüköztürk, 2007). If this coefficient is 0.70 or above, the scale used is considered to be reliable (Bektaş and Akman, 2013). According to Büyüköztürk (2002), factor analysis is an analysis that provides meaningful proposals with fewer and identifiable characteristics from a large number of proposals under the same dimension (Büyüköztürk, 2002). Principal Component Analysis, one of the methods used in factor analysis, is a widely used method. This method creates 
independent and fewer basic components that can be characterized as components of variables (Ersungur et al., 2007).

The statistical tests used in the analysis of the principal components are the Kaiser-Meyer-Olkin (KMO) test and the Bartlett test. The Bartlett test implies that there is a significant and sufficient correlation $(\mathrm{p}<0.05)$ between at least some of the variables in the correlation matrix (Hair et al., 2014). The KMO test is a test that checks the adequacy and suitability of the sample size for the data set (Gürbüz and Yüksel, 2008). The value resulting from this test ranges from 0 to 1 , and a value closer to 1 indicates that the sample size is sufficient and appropriate for the data set (Sanguansat, 2012). In addition, this value should be at least 0.50 and above. However, it is stated that factor loadings of at least $0.30-0.40$ are considered adequate, but in practice, it is assumed that factor loads above 0,50 are considered significant (Hair et al., 2014).

Table 1: Results of Principal Component Analysis

\begin{tabular}{|c|c|c|c|c|c|c|}
\hline $\begin{array}{c}\text { Expressions Regarding } \\
\text { Scales }\end{array}$ & $\begin{array}{l}\text { Factor } \\
\text { Loads }\end{array}$ & Eigenvalue & $\%$ Variance & Cronbach $\alpha$ & KMO Test & BartlettTest \\
\hline \multicolumn{7}{|l|}{ Perceived Value } \\
\hline PV1 & 0,903 & \multirow{3}{*}{2,150} & \multirow{3}{*}{71,65} & \multirow{3}{*}{0,792} & \multirow{3}{*}{0,658} & \multirow{3}{*}{$\begin{array}{c}\chi^{2}=196,970 \\
p=0,000\end{array}$} \\
\hline PV2 & 0,826 & & & & & \\
\hline PV3 & 0,808 & & & & & \\
\hline \multicolumn{7}{|l|}{ Customer Satisfaction } \\
\hline CS1 & 0,896 & \multirow{4}{*}{2,952} & \multirow{4}{*}{73,80} & \multirow{4}{*}{0,881} & \multirow{4}{*}{0,784} & \multirow{4}{*}{$\begin{array}{c}\chi^{2}=443,317 \\
p=0,000\end{array}$} \\
\hline $\mathrm{CS} 2$ & 0,887 & & & & & \\
\hline CS3 & 0,869 & & & & & \\
\hline CS4 & 0,779 & & & & & \\
\hline \multicolumn{7}{|l|}{ Word of Mouth } \\
\hline WOM1 & 0,941 & \multirow{3}{*}{2,125} & \multirow{3}{*}{70,84} & \multirow{3}{*}{0,790} & \multirow{3}{*}{0,573} & \multirow{3}{*}{$\begin{array}{c}\chi^{2}=329,693 \\
p=0,000\end{array}$} \\
\hline WOM2 & 0,936 & & & & & \\
\hline WOM3 & 0,604 & & & & & \\
\hline
\end{tabular}

*PV1. I think I am traveling at a reasonable price with this company. PV2. I think it is worth the time and effort to travel with this company. PV3. Traveling with this company is a more sensible choice when compared to other companies. CS1. I think it's logical to travel with this company. CS2. I'm very satisfied with this company. CS3. This company offers me everything I expect from an airline company. CS4. This company has met all my anticipations until today. WOM1. I say positive things about the airline company I use the most in the people around me. WOM2. I suggest that my friends and acquaintances prefer the airline company I use the most. WOM3. I also tell my complaints about the airline company that

I use the most to other customers and the people around me.

When Table 1 is examined, it is seen that Cronbach $\alpha$ value is over 0.70 for all variables. This indicates that participants' stated participation levels for the proposals in the questionnaire are consistent. In addition, the factor loadings for all expressions exceeded the value of 0.50 , which is assumed to be significant in practice. At the same time, the KMO test result for all dimensions is above the value of 0.50 . This indicates that the sample size is adequate and proper. In addition, the Bartlett Tests $(p=0.000)$ were also significant, indicating that the correlations for the items collected under the scales were significant. It is, therefore, possible to mention the existence of a significant and sufficient correlation between at least some of the variables. The correlation between the factors is shown in Table 2 .

Table 2: Results of Correlation Analysis

\begin{tabular}{|c|c|c|c|}
\hline Factors & Perceived Value & Customer Satisfaction & Word of Mouth \\
\hline Perceived Value & $\mathbf{1}$ & & \\
\hline Customer Satisfaction & $0,736^{* *}$ & $\mathbf{1}$ & \\
\hline Word of Mouth & $0,434^{* *}$ & $0,673^{* *}$ & $\mathbf{1}$ \\
\hline
\end{tabular}

** significant at $99 \%$ confidence level 


\section{H. E. Gürler - R. Erturgut 10/1 (2018) 1-16}

Table 2 shows that there is a significant $(p<0,05)$ and positive correlation (Pear. Corr. $=0,736)$ between perceived value and customer satisfaction, a significant $(p<0,05)$ and positive correlation (Pear. Corr. $=0,434)$ between perceived value and word-ofmouth, and a significant $(\mathrm{p}<0,05)$ and positive correlation (Pear. Corr. $=0,673)$ between customer satisfaction and word-of-mouth. However, it is understood that the highest correlation is between perceived value and customer satisfaction.

Baron and Kenny's mediator effect approach was used to examine whether the customer satisfaction factor is a mediator effect between perceived value and word-ofmouth. Three-step regression analysis was performed in this direction. This analysis has been used in several studies investigating mediating effects (Bitmiş et al., 2013; Kanbur and Kanbur, 2015; Polat and Meyda, 2011; Kahya, 2013).

\section{Baron and Kenny's Approach to Mediator Effect Analysis}

Baron and Kenny (1986) studied the differences between moderator and mediator effects in social psychological research and suggested Figure 1 to explain the mediator effect variable.

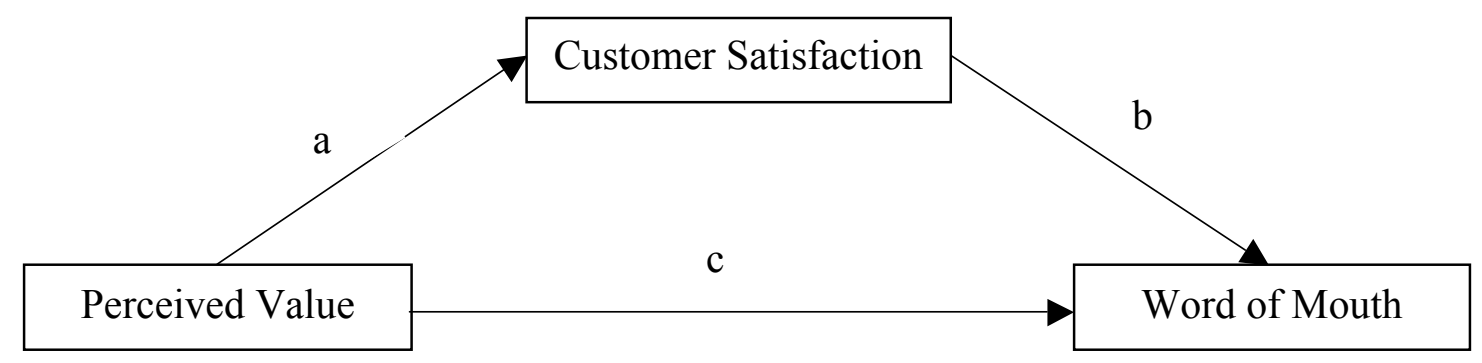

Figure 1: Model for Mediation Effect

According to Baron and Kenny (1986), there is a model as shown in Figure 1 in order to verify the mediation effect. There are three variables in the model, and there are two causal variables (Perceived Value and Customer Satisfaction) that explain the dependent variable (Word-of-Mouth). There are two direct effects: the first one is between perceived value and word-of-mouth (c) and the second one is between perceived value and customer satisfaction (a). Also, there is a mediator effect between customer satisfaction and word-of-mouth (b). If the direct relationship between the perceived value and word-of-mouth is significant while this relationship loses its meaning because of the mediator effect of customer satisfaction we can say that customer satisfaction is a dominant variable. In this case, a full mediation effect is mentioned. The coefficient $\mathrm{c}$ may decrease, although the direct relationship between the perceived value and the word-of-mouth is preserved after adding the customer satisfaction into the model. In this case, a partial mediation effect is mentioned (Baron and Kenny, 1986).

According to Baron and Kenny (1986), three different regression equality assumptions have to be fulfilled in order to understand whether the mediator variable is indeed mediator. These;

1- A significant linear relationship between the perceived value and the word-of-mouth,

2- A significant linear relationship between the perceived value and the customer satisfaction, 
3- A significant linear relationship between the customer satisfaction which is a mediator variable and the word-of-mouth which is a dependent variable. Once these three assumptions have been made, it is possible to talk about the presence of the mediator effect if the effect of the perceived value on word-of-mouth decreases. In addition, the Sobel Test is used to test whether the effect of the detected mediator effect actually exists (Baron and Kenny, 1986).

In order to test the hypotheses $\mathrm{H} 1, \mathrm{H} 2, \mathrm{H} 3$, and $\mathrm{H} 4$ developed using the literature and the model is given in Figure 1, regression analysis was done through statistical package program.

\section{Table 3: Mediating Effect of Customer Satisfaction on the Relationship Between Perceived Value and Word-of-Mouth}

\begin{tabular}{|c|c|c|c|c|c|c|c|c|c|}
\hline \multicolumn{1}{|c|}{ Dependent Variable: Word-of-Mouth } \\
\hline $\begin{array}{c}\text { Independent } \\
\text { Variable }\end{array}$ & $\mathbf{F}$ & $\mathbf{P}$ & $\begin{array}{c}\text { Beta } \\
\text { coefficient }\end{array}$ & S.E. & $\mathbf{T}$ & $\mathbf{P}$ & LLCI & ULCI & VIF \\
\hline $\begin{array}{c}\text { Customer } \\
\text { Satisfaction }\end{array}$ & 156,867 & $0,000^{* *}$ & 0,696 & 0,056 & 12,525 & $0,000^{* *}$ & 0,586 & 0,806 & 1,00 \\
\hline $\mathbf{R}^{2}=0,452$ & \multicolumn{7}{|c|}{ Adjusted $\mathbf{R}^{2}=0,449$} \\
\hline
\end{tabular}

\begin{tabular}{|l|c|c|c|c|c|c|c|c|c|}
\hline \multicolumn{2}{|c|}{ Dependent Variable: Word-of-Mouth } \\
\hline $\begin{array}{c}\text { Independent } \\
\text { Variable }\end{array}$ & $\mathbf{F}$ & $\mathbf{P}$ & $\begin{array}{c}\text { Beta } \\
\text { coefficient }\end{array}$ & S.E. & $\mathbf{T}$ & $\mathbf{P}$ & LLCI & ULCI & VIF \\
\hline Perceived Value & 44,094 & $0,000^{* *}$ & 0,451 & 0,068 & 6,640 & $0,000^{* *}$ & 0,317 & 0,585 & 1,00 \\
\hline $\mathbf{R}^{2}=0,188$ & \multicolumn{2}{|c|}{ Adjusted $\mathbf{R}^{2}=0,184$} \\
\hline
\end{tabular}

\begin{tabular}{|l|c|c|c|c|c|c|c|c|c|}
\hline \multicolumn{2}{|c|}{ Dependent Variable: Customer Satisfaction } \\
\hline $\begin{array}{c}\text { Independent } \\
\text { Variable }\end{array}$ & $\mathbf{F}$ & $\mathbf{P}$ & $\begin{array}{c}\text { Beta } \\
\text { coefficient }\end{array}$ & S.E. & $\mathbf{T}$ & $\mathbf{P}$ & LLCI & ULCI & VIF \\
\hline Perceived Value & 224,816 & $0,000^{* *}$ & 0,709 & 0,047 & 14,994 & $0,000^{* *}$ & 0,615 & 0,802 & 1,00 \\
\hline $\mathbf{R}^{2}=0,542$ & \multicolumn{7}{|c|}{ Adjusted $\mathbf{R}^{2}=0,540$} \\
\hline
\end{tabular}

\begin{tabular}{|c|c|c|c|c|c|c|c|c|c|}
\hline \multicolumn{10}{|c|}{ Dependent Variable for Mediation Effect: Word-of-Mouth } \\
\hline $\begin{array}{l}\text { Bağımsız } \\
\text { Değişken }\end{array}$ & $\mathbf{F}$ & $\mathbf{P}$ & $\begin{array}{c}\text { Beta } \\
\text { coefficient }\end{array}$ & S.E. & $\mathbf{T}$ & $\mathbf{P}$ & LLCI & ULCI & VIF \\
\hline Perceived Value & \multirow[b]{2}{*}{81,054} & \multirow[b]{2}{*}{$0,000 * *$} & $-0,140$ & 0,082 & $-1,708$ & 0,089 & $-0,302$ & 0,022 & \multirow[b]{2}{*}{2,183} \\
\hline $\begin{array}{c}\text { Customer } \\
\text { Satisfaction }\end{array}$ & & & 0,834 & 0,085 & 9,797 & $0,000^{* *}$ & 0,666 & 1,002 & \\
\hline $\mathbf{R}^{2}=0,462$ & \multicolumn{2}{|c|}{$\Delta \mathbf{R}^{2}=0,274^{* *}$} & \multicolumn{3}{|c|}{ Adjusted $\mathbf{R}^{2}=0,456$} & \multicolumn{4}{|c|}{ Durbin-Watson coefficient $=1,837$} \\
\hline Normal theory & for ind & effect $(S$ & el test) $=0,5$ & 2, S.E. & $072, \mathrm{z}=$ & 1885 ve $p=($ & $00 * * *$ & & \\
\hline
\end{tabular}

** significant at $99 \%$ confidence level

The fact that the assumptions of the regression analysis are fulfilled is very important in terms of the accuracy of the analysis. From these assumptions, multicollinearity occurs when there is a very high correlation between the independent variables and represents an undesirable condition in regression analysis. The variance inflation factor (VIF) value is taken into account to detect multicollinearity. This value is 10 or more, indicating that there is a problem of multicollinearity (Albayrak, 2005). In addition, the autocorrelation required for the analysis is measured by the DurbinWatson coefficient, which should range from 1.5 to 2.5 (Büyükşalvarcı and Abdioğlu, 2010). 


\section{H. E. Gürler - R. Erturgut 10/1 (2018) 1-16}

As a result of the regression analysis, it was found that there was a significant linear relationship between perceived value and customer satisfaction and a significant linear relationship between perceived value and word-of-mouth, as well as a significant linear relationship between customer satisfaction and word-of-mouth. After fulfilling these assumptions, it is seen that Beta coefficient of perceived value which explains word-of-mouth is decreased from 0.451 to -0.140 , and the relation explanatory ratio increases from $\mathrm{R}^{2}=0,188$ to $\mathrm{R}^{2}=0.462$. After entering the customer satisfaction into the model, the model had an increase of $\left(\Delta R^{2}\right) 0.274$ in terms of the disclosure with two variables. Moreover, in the normal theory test (Sobel Test) which tests whether the indirect effect is real, it is significant with $p=0,000$ value. Since the coefficient of the perceived value variable is insignificant $(p=0.089)$, it can be said that the customer satisfaction has a full mediator effect function between the perceived value and the word-of-mouth. In other words, there are other multiple-effect variables between perceived value and word-of-mouth. However, it was found that there were no multicollinearity problems among the variables (VIF $<10$ ) and that the Durbin Watson coefficient for all analyzes varied from 1.5 to 2.5. The results obtained for the hypotheses as a result of the analyzes made to test the hypotheses of the study are shown in Table 4.

Table 4: Results of Hypothesis Testing

\begin{tabular}{|c|c|c|}
\hline & Hypothesis & Result \\
\hline $\mathrm{H}_{1}$ & Perceived Value $\longrightarrow$ Customer Satisfaction & Supported \\
\hline $\mathrm{H}_{2}$ & Perceived Value $\longrightarrow$ Word-of-Mouth & Supported \\
\hline $\mathrm{H}_{3}$ & Customer Satisfaction $\longrightarrow$ Word-of-Mouth & Supported \\
\hline $\mathrm{H}_{4}$ & Perceived Value $\longrightarrow$ Customer Satisfaction $\longrightarrow$ Word-of-Mouth & Supported \\
\hline
\end{tabular}

Table 4 shows that all the hypotheses of the study are supported. This implies that a significant and linear relationship between perceived value and customer satisfaction, a significant and linear relationship between perceived value and word-of-mouth, and a significant and linear relationship between customer satisfaction and word-of-mouth was determined. Furthermore, it has been determined that customer satisfaction has a full mediator effect on the significant and linear relationship between the perceived value and the word-of-mouth.

\section{Conclusion, Recommendations, And Limitations}

Before analyzing the meaningful relationship between perceived value, customer satisfaction, and word-of-mouth, and the mediating effect of the customer satisfaction on this relationship, reliability analysis of variables was performed. As a result of this analysis, questions about variables were found to be reliable. As a result of correlation analysis, it was found that there were significant and positive relations between all variables. Then the mediation effect was tested by regression method.

When the linear relationship between perceived value and word-of-mouth is examined, it is seen that perceived value discloses $18 \%$ of word-of-mouth and the effect ratio is 0,451 . This indicates that perceived value is not enough to explain word-ofmouth, and other variables must be included in the model. It has been determined that the customer satisfaction has an effect on both perceived value and word-of-mouth. In this case, it is thought that airline companies, which will provide their customers with a reasonable price, time and effort to travel and making a sensible choice as a substitute, will be one step ahead of their competitors. 


\section{H. E. Gürler - R. Erturgut 10/1 (2018) 1-16}

The Sobel test, which examined whether the mediation effect is meaningful, was significant $(p=0,000)$. In addition, the significant relationship between perceived value and word-of-mouth lost meaningfulness $(p=0.089)$ after the customer satisfaction variable was included in the model. According to these findings, the customer satisfaction variable is a full mediator effect. Therefore it is recommended that airline companies operating in the sector should provide services that can increase the satisfaction level of the customers. Because at the end of the study; it has been determined that the value that the customers perceived is not enough to talk about positively about the company. Customers need to be satisfied as well as the positive value they perceive in order to have positive referrals to the firm.

The mediating effect of customer satisfaction has been investigated in several studies and it has been found that it plays a mediator role in the relationship between different variables. For example; Osman and Sentosa (2003) studied the tourism industry in Malaysia, in their research they found that the customer satisfaction has a mediator effect on the relationship between service quality and customer loyalty. AlHawari and Ward (2006) studied the banking industry in Australia, in their research they found that the customer satisfaction has a mediator effect on the relationship between automated service quality and financial performance. Usta and Memiş (2009) studied the mobile communication industry in Turkey, in their research they found that the customer satisfaction has a mediator effect on the relationship between service quality and brand loyalty. Chumpitaz and Swaen (2002) studied in the airline industry, in their research they found that the customer satisfaction has a mediator effect on the relationship between service quality and brand loyalty. Mosahab et al. (2010) studied the banking industry in İran, in their research they found that the customer satisfaction has a mediator effect on the relationship between service quality and service loyalty. These findings are similar to the findings in this study, although the variables that the customer satisfaction has a mediator effect on are different.

The first limitation of this study is about the size of the sample. The number of the universe is unknown. According to Yazıcıoğlu and Erdoğan (2011), the sample size to be determined for the universes in the size of 100 million should be at least 384 . However, due to the time constraints of the researchers, 192 valid questionnaires were obtained. The other limitation of this study is to consider the present feelings of participants. Research results reflect the opinions of individuals at a specific time interval or after a certain number of experiences. Hence, positive or negative experiences that individuals may experience in later days may lead to different outcomes. 


\section{References}

Agus, A., Abdullah, M. (2000). "The mediating effect of customer satisfaction on TQM practices and financial performance", Singapore Management Review, Vol. 22, No. 2, 55-73.

Air Transport Action Group. (2016). Aviation: Benefits Beyond Borders. Switzerland.

Albayrak, A. S. (2005). "Çoklu doğrusal bağlantı halinde enküçük kareler tekniğinin alternatifi yanlı tahmin teknikleri ve bir uygulama", Uluslararası Yönetim İktisat ve İşletme Dergisi, Vol. 1, No. 1, 105-126.

Al-Hawari, M., Ward, T. (2006). "The effect of automated service quality on Australian banks' financial performance and the mediating role of customer satisfaction", Marketing Intelligence and Planning, Vol. 24, No. 2, 127-147.

Al-Sabbahy, H. Z., Ekinci, Y., Riley, M. (2003). "An examination of perceived value dimensions in the hospitality industry", In Proceedings of the Travel and Tourism Research Association Conference. New Brunswick: St. John.

Arif, M., Gupta, A., Williams, A. (2013). "Customer service in the aviation industry-An exploratory analysis of UAE airports", Journal of Air Transport Management, Vol. 32, 1-7.

Baron R. M., Kenny D. A. (1986). "The moderator-mediator variable distinction in social psychological research: conceptual, strategic, and statistical considerations", Journal of Personality and Social Psychology, Vol. 51, No. 6, 1173-1182.

Bektaş, H., Akman, S. U. (2013). "Yükseköğretimde hizmet kalitesi ölçeği: güvenilirlik ve geçerlilik analizi", Ekonometri ve İstatistik Dergisi, No. 18, 116-133.

Bitmiş, M. G., Sökmen, A., Turgut, H. (2013). "Psikolojik dayanıklılığın tükenmişlik üzerine etkisi: örgütsel özdeşleşmenin aracılık rolü”, İktisadi ve İdari Bilimler Fakültesi Dergisi, Vol. 15, No. 2, 27-40.

Büyüköztürk, S. (2007). Sosyal bilimler için veri analizi el kitabi (8. Baski), Pegem Yayincilik, Ankara.

Büyüköztürk, Ş. (2002). "Faktör analizi: Temel kavramlar ve ölçek geliştirmede kullanımı", Kuram ve Uygulamada Eğitim Yönetimi, Vol. 32, No. 32, 470-483.

Büyükşalvarc1, A., Abdioğlu, H. (2010). "Kriz öncesi ve kriz dönemlerinde işletmelerde çalışma sermayesi gereksiniminin belirleyicileri: IMKB imalat sanayi şirketleri üzerine ampirik bir uygulama", Atatürk Üniversitesi İktisadi ve İdari Bilimler Dergisi, Vol. 24, No. 2, 47-71.

Calvo-Porral, C., Lévy-Mangin, J. P. (2015). "Switching behavior and customer satisfaction in mobile services: Analyzing virtual and traditional operators", Computers in Human Behavior, Vol. 49, 532-540.

Chen, C. F. (2008). "Investigating structural relationships between service quality, perceived value, satisfaction, and behavioral intentions for air passengers: Evidence from Taiwan", Transportation Research Part A: Policy and Practice, Vol. 42, No. 4, 709-717.

Chen, C. F., Tsai, M. H. (2008). "Perceived value, satisfaction, and loyalty of TV travel product shopping: Involvement as a moderator", Tourism Management, Vol. 29, No. 6, 1166-1171. 
Chumpitaz, R., Swaen, V. (2002). "Service quality and brand loyalty relationships: Investigating the mediating effect of customer satisfaction", 31st European Marketing Academy Conference, Braga, Portugal. 1-7.

Cronin, J. J., Brady, M. K., Hult, G. T. M. (2000). “Assessing the effects of quality, value, and customer satisfaction on consumer behavioral intentions in service environments", Journal of Retailing, Vol. 76, No. 2, 193-218.

Çatı, K., Koçoğlu, C. M. (2008). "Müşteri sadakati ile müşteri tatmini arasındaki ilişkiyi belirlemeye yönelik bir araştırma", Selçuk Üniversitesi Sosyal Bilimler Enstitüsü Dergisi, No. 19, 167-188.

Deng, Z., Lu, Y., Wei, K. K., Zhang, J. (2010). "Understanding customer satisfaction and loyalty: An empirical study of mobile instant messages in China", International Journal of Information Management, Vol. 30, No. 4, 289300.

Directorate General of Civil Aviation. (2016). Activity Report of Directorate General of Civil Aviation. Turkey.

Eggert, A., Ulaga, W. (2002). "Customer perceived value: a substitute for satisfaction in business markets?", Journal of Business and Industrial Marketing, Vol. 17, No. 2/3, 107-118.

Ersungur, Ş. M., Kızıltan, A., Polat, Ö. (2007). “Türkiye'de bölgelerin sosyo-ekonomik gelişmişlik sıralaması: temel bileşenler analizi", Atatürk Üniversitesi İktisadi ve İdari Bilimler Dergisi, Vol. 21, No. 2, 55-66.

Gallarza, M. G., Saura, I. G. (2006). "Value dimensions, perceived value, satisfaction and loyalty: an investigation of university students' travel behaviour", Tourism Management, Vol. 27, No. 3, 437-452.

Gürbüz, S., Yüksel, M. (2008). “Çalışma ortamında duygusal zeka: iş performansı, iş tatmini, örgütsel vatandaşlık davranışı ve bazı demografik özelliklerle ilişkisi”, Doğuş Üniversitesi Dergisi, Vol. 9, No. 2, 174-190.

Hair Jr, J. F., Black W.C., Babin B.J., Anderson R. E. (2014). Multivariate data analysis, 7. Edition, Pearson New International Edition.

Hartline, M. D., Jones, K. C. (1996). "Employee performance cues in a hotel service environment: Influence on perceived service quality, value, and word-of-mouth intentions", Journal of Business Research, Vol. 35, No. 3, 207-215.

Hsu, C. Y., Huang, Y. W., Chuang, S. H. (2017). "Examining the relationships among electronic word of mouth, perceived value, and risk, and consumer purchase intention", In International Conference on Innovative Mobile and Internet Services in Ubiquitous Computing. Springer, Cham, 795-801.

Hsu, H. (2006). "An empirical study of web site quality, customer value, and customer satisfaction based on e-shop", The Business Review, Vol. 5, No. 1, 190-193.

Hui, T. K., Wan, D., Ho, A. (2007). "Tourists' satisfaction, recommendation and revisiting Singapore", Tourism Management, Vol. 28, No. ), 965-975.

IATA-International Air Transport Association. Annual Review 2017.

Işık, E. S. (2010). Havayolu ulaşımında hizmet kalitesinin ölçümü: iç hatlarda pilot uygulama. Published master's thesis, Police Academy, Turkey. 
Jen, W., Hu, K. C. (2003). "Application of perceived value model to identify factors affecting passengers' repurchase intentions on city bus: A case of the Taipei metropolitan area", Transportation, Vol. 30, No. 3, 307-327.

Jiewanto, A., Laurens, C., Nelloh, L. (2012). "Influence of service quality, university image, and student satisfaction toward WOM intention: a case study on Universitas Pelita Harapan Surabaya", Procedia-Social and Behavioral Sciences, Vol. 40, 16-23.

Jung, N. Y., Seock, Y. K. (2017). "Effect of service recovery on customers' perceived justice, satisfaction, and word-of-mouth intentions on online shopping websites", Journal of Retailing and Consumer Services, Vol. 37, 23-30.

Kahya, C. (2013). "Örgütsel sinizm, iş performansını etkiler mi? İş tatmininin aracılık etkisi”, Global Journal of Economics and Business Studies, Vol. 2, No. 3, 34-46.

Kanbur, A., Kanbur, E. (2015). "Lider-üye etkileşiminin örgütsel sinizme etkisi: algılanan içsellik statüsünün aracılık rolü”, Journal of World of Turks, Vol. 7, No. 2, 193-216.

Karaca, A. D. (2015). Türkiye'de havayolu ulaşımında havaalanlarının yeri ve çevresel etkileri: Sabiha Gökçen havalimanı örneği. Published master's thesis, University of Istanbul, Turkey.

Kim, T. T., Kim, W. G., Kim, H. B. (2009). "The effects of perceived justice on recovery satisfaction, trust, word-of-mouth, and revisit intention in upscale hotels", Tourism Management, Vol. 30, No. 1, 51-62.

Kuo, Y. F., Wu, C. M., Deng, W. J. (2009). “The relationships among service quality, perceived value, customer satisfaction, and post-purchase intention in mobile value-added services", Computers in Human Behavior, Vol. 25, No. 4, 887-896.

Lai, T. L. (2004). "Service quality and perceived value's impact on satisfaction, intention, and usage of short message service (SMS)", Information Systems Frontiers, Vol. 6, No. 4, 353-368.

Lai, W. T., Chen, C. F. (2011). "Behavioral intentions of public transit passengers-The roles of service quality, perceived value, satisfaction and involvement", Transport Policy, Vol. 18, No. 2, 318-325.

Leisen Pollack, B., Leisen Pollack, B. (2017). "Effects of exit barriers on word of mouth activities", Journal of Services Marketing.

Lu, H. Y., Wu, W. Y., Chen, S. H. (2016). "Influences on the perceived value of medical travel: the moderating roles of risk attitude, self-esteem, and word-ofmouth", Current Issues in Tourism, Vol. 19, No. 5, 477-491.

Marangoz, M. (2007). “A ğızdan ağıza iletişimin müşterilerin satın alma davranışlarına etkileri: Cep telefonu pazarına yönelik bir araştırma", Çukurova Üniversitesi Sosyal Bilimler Enstitüsü Dergisi, Vol. 16, No. 2, 395-412.

Maxham III, J. G., Netemeyer, R. G. (2002). "A longitudinal study of complaining customers' evaluations of multiple service failures and recovery efforts", Journal of Marketing, Vol. 66, No. 4, 57-71.

Meesala, A., Paul, J. (2016). "Service quality, consumer satisfaction and loyalty in hospitals: Thinking for the future", Journal of Retailing and Consumer Services. 
Mishra, P., Bakshi, M., Singh, R. (2016). "Impact of consumption emotions on WOM in movie consumption: Empirical evidence from emerging markets", Australasian Marketing Journal (AMJ), Vol. 24, No. 1, 59-67.

Mohd-Any, A. A., Winklhofer, H., Ennew, C. (2015). "Measuring users' value experience on a travel website (e-value) what value is cocreated by the user?", Journal of Travel Research, Vol. 54, No. 4, 496-510.

Mosahab, R., Mahamad, O., Ramayah, T. (2010). "Service quality, customer satisfaction, and loyalty: A test of mediation", International Business Research, Vol. 3, No. 4, 72-80.

Murray, D., Howat, G. (2002). "The relationships among service quality, value, satisfaction, and future intentions of customers at an Australian sports and leisure centre", Sport Management Review, Vol. 5, No. 1, 25-43.

Naktiyok, A., Küçük, O. (2003). "İşgören (iç müşteri) ve müşteri (dış müşteri) tatmini, işgören tatmininin müşteri tatmini üzerine etkileri: ampirik bir değerlendirme", Atatürk Üniversitesi İktisadi ve İdari Bilimler Dergisi, Vol. 17, No. 1-2, 225-243.

Osman, Z., Sentosa, I. (2013). "Mediating effect of customer satisfaction on service quality and customer loyalty relationship in Malaysian rural tourism", International Journal of Economics Business and Management Studies, Vol. 2, No. 1, 25-37.

Pereira, H. G., Salgueiro, M. F., Rita, P. (2016). "Online purchase determinants of loyalty: The mediating effect of satisfaction in tourism", Journal of Retailing and Consumer Services, Vol. 30, 279-291.

Petrick, J. F. (2004). "The roles of quality, value, and satisfaction in predicting cruise passengers' behavioral intentions", Journal of Travel Research, Vol. 42, No. 4, 397-407.

Petrick, J. F., Backman, S. J. (2002). “An examination of the construct of perceived value for the prediction of golf travelers' intentions to revisit". Journal of Travel Research, Vol. 41, No. 1, 38-45.

Pizam, A., Ellis, T. (1999). "Customer satisfaction and its measurement in hospitality enterprises", International Journal of Contemporary Hospitality Management, Vol. 11, No. 7, 326-339.

Pizam, A., Pizam, A., Shapoval, V., Shapoval, V., Ellis, T., Ellis, T. (2016). "Customer satisfaction and its measurement in hospitality enterprises: a revisit and update", International Journal of Contemporary Hospitality Management, Vol. 28, No. 1, 2-35.

Polat, M., Meyda, C. H. (2011). "Örgüt kültürü bağlamında güç eğilimi ve örgütsel bağll1ık ilişkisinde örgütsel özdeşleşmenin aracılık rolü”, Atatürk Üniversitesi İktisadi ve İ́dari Bilimler Dergisi, Vol. 25, No. 1, 153-170.

Qin, H., Prybutok, V. R., Zhao, Q. (2010). "Perceived service quality in fast-food restaurants: empirical evidence from China", International Journal of Quality and Reliability Management, Vol. 27, No. 4, 424-437.

Ranaweera, C., Prabhu, J. (2003). "On the relative importance of customer satisfaction and trust as determinants of customer retention and positive word of 


\section{H. E. Gürler - R. Erturgut 10/1 (2018) 1-16}

mouth", Journal of Targeting, Measurement and Analysis for Marketing, Vol. 12, No. 1, 82-90.

Rothkoph, M., Wald, A. (2008). "The role of innovation in the increasingly commoditized airline industry-insights from case studies", Air Transport Research Society, 8-11.

Sanguansat, P. (Ed.). (2012). Principal component analysis-multidisciplinary applications, InTech, Croatia.

San-Martín, S., Prodanova, J., Jiménez, N. (2015). "The impact of age in the generation of satisfaction and WOM in mobile shopping", Journal of Retailing and Consumer Services, Vol. 23, 1-8.

Srivastava, M., Rai, A. K. (2013). "Investigating the mediating effect of customer satisfaction in the service quality-customer loyalty relationship", Journal of Consumer Satisfaction, Dissatisfaction and Complaining Behavior, Vol. 26, 95109.

Turel, O., Serenko, A. (2006). "Satisfaction with mobile services in Canada: An empirical investigation”, Telecommunications Policy, Vol. 30, No. 5, 314-331.

Tütüncü, Ö., Doğan, Ö. (2003). "Müşteri tatmini kapsamında öğrenci memnuniyetinin ölçülmesi”, Dokuz Eylül Üniversitesi Sosyal Bilimler Enstitüsü Dergisi, Vol. 5, No. 4, 130-151.

Usta, R., Memiş, S. (2009). "Hizmet kalitesi ve marka bağlılığı arasındaki ilişki üzerine müşteri tatmininin aracılık etkisi”, Atatürk Üniversitesi İktisadi ve İdari Bilimler Dergisi, Vol. 23, No. 4, 87-108.

Vespermann, J., Wald, A. (2011). "Much ado about nothing?-an analysis of economic impacts and ecologic effects of the EU-emission trading scheme in the aviation industry", Transportation Research Part A: Policy and Practice, Vol. 45, No. 10, 1066-1076.

Wahab, N. A., Hassan, L. F. A., Shahid, S. A. M., Maon, S. N. (2016). "The relationship between marketing mix and customer loyalty in hijab industry: the mediating effect of customer satisfaction", Procedia Economics and Finance, Vol. 37, 366-371.

Webber, S. S. (2011). "Dual organizational identification impacting client satisfaction and word of mouth loyalty", Journal of Business Research, Vol. 64, No. 2, 119125.

Wien, A. H., Olsen, S. O. (2017). "Producing word of mouth-a matter of selfconfidence? Investigating a dual effect of consumer self-confidence on WOM", Australasian Marketing Journal (AMJ), Vol. 25, No. 1, 38-45.

Williams, P., Soutar, G. N. (2009). "Value, satisfaction and behavioral intentions in an adventure tourism context", Annals of Tourism Research, Vol. 36, No. 3, 413438.

Woodruff, R. B. (1997). "Customer value: the next source for competitive advantage", Journal of the Academy of Marketing Science, Vol. 25, No. 2, 139153.

Yang, H., Yu, J., Zo, H., Choi, M. (2016). "User acceptance of wearable devices: An extended perspective of perceived value", Telematics and Informatics, Vol. 33, No. 2, 256-269. 
H. E. Gürler - R. Erturgut 10/1 (2018) 1-16

Yang, Z., Peterson, R. T. (2004). "Customer perceived value, satisfaction, and loyalty: The role of switching costs", Psychology and Marketing, Vol. 21, No. 10, 799822.

Yazıcıoğlu, Y., Erdoğan, S. (2011). SPSS uygulamalı bilimsel araştırma yöntemleri, Detay Yayıncilık, Ankara.

Zeithaml, V. A. (1988). "Consumer perceptions of price, quality, and value: a meansend model and synthesis of evidence", The Journal of Marketing, Vol. 52, No. 3, $2-22$. 